\title{
CAN HISTORIES BE TRUE? NARRATIVISM, POSITIVISM, AND THE "METAPHORICAL TURN"1
}

\author{
CHRIS LORENZ
}

\begin{abstract}
Narrativism, as represented by Hayden White and Frank Ankersmit, can fruitfully be analyzed as an inversion of two brands of positivism. First, narrativist epistemology can be regarded as an inversion of empiricism. Its thesis that narratives function as metaphors which do not possess a cognitive content is built on an empiricist, "picture view" of knowledge. Moreover, all the non-cognitive aspects attributed to narrative as such are dependent on this picture theory of knowledge and a picture theory of representation. Most of the epistemological characteristics that White and Ankersmit attribute to historical narratives therefore share the problems of this picture theory.

The article's second thesis is that the theories of narrative explanation can also fruitfully be analyzed as inversions of positivist covering-law theory. Ankersmit's brand of narrativism is the most radical in this respect because it posits an opposition between narrative and causal modes of comprehension while simultaneously eliminating causality from narrativist historical understanding. White's brand of narrativism is more of a hybrid than is Ankersmit's as far as its theory of explanation is concerned; nevertheless, it can also be fruitfully interpreted as an inversion of covering-law theory, replacing it by an indefinite multitude of explanatory strategies.

Most of the striking characteristics of both White's and Ankersmit's narrativism presuppose positivism in these two senses, especially their claim that historical narratives have a metaphorical structure and therefore no truth-value. These claims are hard to reconcile with the factual characteristics of debates by historians; this problem can be tracked down to the absence in "metaphorical" narrativism of a conceptual connection between historical narratives and historical research.
\end{abstract}

\section{INTRODUCTION}

My aim in this essay is to unearth and to criticize certain deep presuppositions of what I shall call "metaphorical narrativism." To this end, I shall lump together under this label the two quite distinct philosophies of history of Hayden White and Frank Ankersmit. ${ }^{2}$ Because of their intellectual efforts-preceded by a few

1. I am indebted to the Von Humboldt Foundation for financial support in the form of a Von Humboldt Research Award and to Larry Griffin (Vanderbilt University), Jörn Rüsen (Bielefeld University), Axel van den Berg (McGill University), the participants of the "Social History" colloquium at the "Arbeitstelle für Vergleichende Gesellschaftsgeschichte" in Berlin in Spring 1997.

2. Their major books are: Hayden White, Metahistory: The Historical Imagination in Nineteenth-Century Europe (Baltimore, 1973); Tropics of Discourse: Essays in Cultural Criticism (Baltimore, 1978); The Content of the Form: Narrative Discourse and Historical Representation (Baltimore, 1987). F. R. Ankersmit, Narrative Logic: A Semantic Analysis of the Historian's Language (Groningen, 1981 and The Hague, 1983); Denken over geschiedenis: Een overzicht van 
others', such as William Walsh and Louis Mink-philosophy of history has in the recent past drifted away from philosophy of science and social science in the direction of philosophy of art, literature, rhetoric, and aesthetics. This move was a conscious reaction to the dominant view of the previous decades, that is, to the positivist conception of (social) science. In this article I shall argue that metaphorical narrativism can be understood both as a frontal attack against positivism and, more importantly, in specific respects as its reversal (thereby continuing to share its presuppositions).

I will not try to analyze White's and Ankersmit's metaphorical narrativisms in toto, but concentrate on two conceptual issues that have aroused as much attention as confusion. ${ }^{3}$ The first issue is their thesis that the narrative form of history implies that the notion of truth as correspondence cannot be applied to historical stories in contrast with the individual statements that collectively make up these stories. Historical narratives therefore are characterized by them as "fictional" and/or "metaphorical." The second issue is their thesis that narratives are selfexplanatory and explanation by narrative excludes causal explanation. Both theses contradict the intuitions of some working historians and therefore deserve closer examination.

It makes good sense to analyze metaphorical narrativism as a counter-position to positivism in both its guises. First, metaphorical narrativism developed in opposition to positivism with a small $\mathrm{p}$, that is the positivism of facts, alias empiricism. Second, it developed in opposition to Positivism with a capital $\mathrm{P}$, that is the covering-law view of explanation. Metaphorical philosophy of history deliberately attacked the main tenets of positivism and analytical philosophy.

moderne geschiedfilosofische opvattingen (Groningen, 1984); De navel van de geschiedenis: Over interpretatie, representatie en historische realiteit (Groningen, 1990); History and Tropology: The Rise and Fall of Metaphor (Berkeley, 1994); De spiegel van het verleden. Exploraties I: Geschiedtheorie (Kampen, 1996); De macht van representatie. Exploraties II: Cultuurfilosofie \& esthetica (Kampen, 1996); Macht door representatie. Exploraties III: Politieke filosofie (Kampen, 1997); Aesthetic Politics: Political Philosophy beyond Fact and Value (Stanford, 1998). My references to Narrative Logic are to the 1981 edition. As my main goal is to analyze the conceptual structure of metaphorical narrativism I will neglect the historical development of both White's and Ankersmit's positions and, where necessary, deal with it in the notes.

3. For the discussions on White cf. L. Kramer, "Literature, Criticism and Imagination: The Literary Challenge of Hayden White and Dominick LaCapra," in The New Cultural History, ed. Lynn Hunt (Berkeley, 1989), 97-128; Noël Carroll, "Interpretation, History and Narrative," The Monist 73 (1990), 134-167; Paul Roth, "Hayden White and the Aesthetics of History," History of the Human Sciences 5 (1992), 17-35; Wulf Kansteiner, "Hayden White's Critique of the Writing of History," History and Theory 32 (1993), 273-296; John Zammito, "Are We Being Theoretical Yet? The New Historicism, the New Philosophy of History and 'Practicing' Historians," Journal of Modern History 65 (1993), 783-814; two issues of Storia della Storiografia (Geschichte der Geschichtsschreibung) 24 (1993) and 25 (1994) concerning White's Metahistory; Paul Ricoeur, "Geschichte und Rhetorik," in Der Sinn des Historischen: Geschichtsphilosophische Debatten, ed. H. Nagl-Docekal (Frankfurt am Main, 1996), 107-126; Richard T. Vann et al., "Forum: Hayden White: Twenty-Five Years On," History and Theory 37 (1998), 143-194. For Ankersmit cf. Hans Kellner, "Narrativity in History: Post-structuralism and Since," History and Theory, Beiheft 26 (1987) (The Representation of Historical Events), 18-22; Perez Zagorin, "Historiography and Postmodernism: Reconsiderations," History and Theory 29 (1990), 263-296; and my "Het masker zonder gezicht. F. R. Ankersmit's filosofie van de geschiedschrijving," Tijdschrift voor Geschiedenis 97 (1984), 169-194. 
First, White and Ankersmit reject the presupposition that the narratio is just a collection of individual, descriptive statements and that its explanatory logic can be analyzed in these terms. With regard to narratives this tenet of analytical philosophy is thus thrown in the philosophical garbage can and replaced by the notion of the autonomous narrative. The narratio is now introduced as an autonomous linguistic entity with formal properties that transcend the level of the descriptive (singular existential) statement, although the narratio is built out of such statements.

White and Ankersmit argue for the autonomy of the narrative because in their view the narrative possesses features that cannot be reduced to those of its statements. According to White the plot-structure of narratives is such a nonreducible quality. Therefore White characterizes the historical narrative as an "extended metaphor." 4 According to Ankersmit, the same set of statements can be connected from different points of view-with different interpretations or narrative substances (later labeled as historical representations ${ }^{5}$ ) as a result. The crucial narrativistic message in this context is that neither the mode of emplotment nor the viewpoint can be located in reality but only in the linguistic universe of narrative. It is the historian who imposes a linguistic, literary structure on the past—in the past nothing real corresponds to it. ${ }^{6}$ Whoever forgets this will fall victim to the "fictions of factual representation," in White's famous phrase.

4. White, "The Historical Text as Literary Artifact," in Tropics of Discourse, 91.

5. To prevent confusion it is essential to note from the outset that Ankersmit's concept of representation is fundamentally different from Rorty's. Rorty identifies representation in epistemology with mirroring objects in the mind of a knowing subject—and from there he develops his own antirepresentationalist position. Ankersmit, however, taking a lead from Gombrich, Goodman, and Danto, identifies representation not with mirroring, but with an uncodified way of substituting an object for its symbolic representation. As soon as the process of representation is codified, it stops being interesting as representation and is relegated to the domain of epistemology.

Rorty's concept of representation, however, is problematical, because all representation is representation for knowing subjects. Fundamental for representation is not mirroring, but maintenance of structure with a reduction and induction of complexity at the same time. See T. Mormann, "Ist der Begriff der Repräsentation obsolet?," Zeitschrift für philosophische Forschung 51 (1997), 349-366.

6. White's argument is based on the presumed differences of lives and stories. "Lives are lived and stories are told," according to White (and Mink), who therefore conclude that (hi)stories about lives must be structurally different from the lives themselves and can't be realistically "copied" in the story form. For a fundamental critique of this remarkable argument see Carroll, "Interpretation, History and Narrative," 144-145. In contrast to Ankersmit, White sometimes plays with the notion of "narrative truth." It is evident, however, that for White narrative truth cannot be interpreted according to the correspondence theory of truth given his emphasis on the imposition of literary structures by the historian. What "narrative truth" means therefore remains obscure. In "Narrative in Contemporary Literary Theory," in Content of the Form, 48, he merely states that his literary analysis of history writing raises "the more general question of the truth of literature itself." Further he claims that ignoring the "specifically literary aspect of historical narrative" leads to ignoring "whatever truth it may convey in figurative terms." But before, on 46, he has stated: "But the 'truth' of narrative form can display itself only indirectly, that is to say by means of allegoresis. What else could be involved in the representation of a set of real events as, for example, a tragedy, a comedy, or farce?" In "Figuring the Nature of the Times Deceased': Literary Theory and Historical Writing," in The Future of Literary Theory, ed. R. Cohen (New York and London, 1989), the same ambiguity pertains: "Stories are told or written, not found. And as for the notion of a 'true' story, this is virtually a contradiction in terminis. All stories are fictions. Which means, of course, that they can be true only in a metaphorical sense and in the sense in which a figure of speech can be true. Is this true enough?" Cf. Carroll, "Interpretation, History and Narrative," 135-136.

7. White, "The Fictions of Factual Representation," in Tropics of Discourse, 121-134. 
Both White and Ankersmit present the metaphorical quality of narratios as the-emergent-property of the narratio. White's claims in this respect are stronger: according to him narratios have a metaphorical structure and are (extended) metaphors; according to Ankersmit narratios function merely as metaphors. Both authors claim that what historians do when they write narratives is essentially create points of view in the way metaphors do: in this way they create an order in a chaos of phenomena and explain it (in a sense to be analyzed). ${ }^{8}$ Therefore, according to this argument, metaphorical descriptions at the same time constitute explanations of the phenomena so described and thus narratives are self-explanatory. ${ }^{9}$ Both authors keep emphasizing that this order is an imposed construction by the historian on real phenomena and is not found in them or arrived at by factual research and inductive reasoning. This move in the discussion-this identification of stories of historians and "imposed" metaphors-is the crucial one in modern narrativistic philosophy of history.

\section{NARRATIVISM AS INVERTED POSITIVISM (1): NARRATIVISM AS AN INVERSION OF THE "POSITIVISM OF FACTS"}

The metaphorical turn for narrative philosophy of history constitutes a frontal attack on the tenets of positivism (with a p and a P). ${ }^{10}$ In this section I shall examine its attack on the positivism of facts, or empiricism. White and Ankersmit both identify this type of positivism with the convictions of the "traditional" historians. In the "traditional" view narrative composition (Darstellung) is conceived as the by-product of historical research (Forschung). So the relationship between the historian and the past is similar to the one between the record player and the record. ${ }^{11}$ Therefore-still according to White and Ankersmit- "traditional" historians hold the opinion that the truth of their narratives is just the byproduct of the truth of their research: narratives are seen essentially as entities without an organizational principle of their own. ${ }^{12}$

8. The presupposition that the past is just a chaos of phenomena is an important one in metaphorical narrativism. In this way the radically constructive element of the "narrativization" of the past is made plausible. For criticism of this presupposition and a more realistic approach see my "Historical Knowledge and Historical Reality: A Plea for Internal Realism," History and Theory 33 (1994), 297327.

9. For White, in contrast with Ankersmit, metaphorical explanation or explanation by emplotment is just one mode of historical explanation by narrative, next to explanation by formal argument and explanation by ideological implication. I will not examine White's claims in this respect for simplicity's sake and just focus on his explanation by emplotment. Cf. his Metahistory, Introduction.

10. Ankersmit's philosophy is more systematic with respect to metaphor than is White's. Cf. Ankersmit, Narrative Logic, chapter 7 ("Narrative Substances and Metaphor"). For White's position cf. his "The Historical Text as a Literary Artifact," 91: "The 'overall coherence' of a given 'series' of historical facts is the coherence of story, but this coherence is achieved only by a tailoring of the 'facts' to the requirement of the story form." "It is this mediative function that permits us to speak of a historical narrative as an extended metaphor."

11. For Ankersmit's statement of the problem and the comparison of the historian with a pickupneedle cf. his De navel van de geschiedenis, 20-21. For White's statement see note 16.

12. Cf. White, "The Question of Narrative in Contemporary Historical Theory," 27: "For the narrative historian, the historical method consists in investigating the documents in order to determine what is the true or most plausible story that can be told about the events of which they are evidence. 
When we look at the metaphorical turn in narrative philosophy of history in its opposition to this brand of positivism we can observe an interesting feature: the type of narrativism defended by White and Ankersmit represents the simple negation or reversal of the traditional positivistic view. Therefore it shares its fundamental conceptual structure. By this I refer to two characteristic conceptual oppositions. First, both positions share a specific argumentative logic, which Richard Bernstein aptly labeled the "either-or logic," alias the Cartesian Anxiety. According to this (originally theological) argumentative scheme, arbitrariness and chaos constitute the only alternatives for a firm foundation: either knowledge claims can be firmly founded in empirical data, or claims to knowledge are arbitrary and a sheer figment of imagination. Fantasy is thus presupposed to be the only alternative for and only opposition to foundation. ${ }^{13}$ As we shall see, this argument is used by White and Ankersmit to claim a non-cognitive status for historical narratives. Second, I refer to the opposition of literal to figurative uses of language. After all, positivism had banned all figurative, metaphorical use of language from science-including history-because it presupposed that, in contrast to the literal, descriptive, or referential use of language (that gives us information about reality), metaphorical language consisted of "mere words" (that provide no information about reality at all). Therefore only the literal use of language was regarded as cognitive and capable of being true or untrue. This opposition between literal and metaphorical language-presupposed in positivism-is retained in "metaphorical" narrativism in an inverted form: now descriptive statements are treated as mere information, hardly worth a serious philosopher's attention, and metaphorical language is upgraded to the real thing. ${ }^{14}$

A true narrative account, according to this view, is less a product of the historian's poetic talents, as the narrative account of imaginary events is conceived to be, than it is the necessary result of the proper application of historical 'method.' The form of discourse, the narrative, adds nothing to the content of the representation; rather it is a simulacrum of the structure and processes of real events. And insofar as this representation resembles the events that it represents, it can be taken as a true account." For White's view on the relationship between a chronicle and narrative see 43: "In historical discourse, the narrative serves to transform into a story a list of historical events that would otherwise be only a chronicle." It is most significant, however, to observe that the first historian who wrote a systematic treatise on "doing history," Johann-Gustav Droysen in his Historik, does not fit in this "traditional" picture at all.

13. Cf. B. Bernstein, Beyond Objectivism and Relativism (Oxford, 1983), 16-25, esp. 18: "Either there is some support for our being, a fixed foundation for our knowledge, or we cannot escape the forces of darkness that envelop us with madness, with intellectual and moral chaos." An "anything goes" skepticism, therefore, is the only alternative for foundationalism.

14. Cf. White, "The Question of Narrative in Contemporary Historical Theory," 48-49, on the relationship between literal and figurative use of language and on the impossibility of reducing the latter to the former. In the discussion with his critics in his more recent "Literary Theory and Historical Writing," 22-33, White relativizes all the conceptual oppositions that are central to his tropological theory-between the literal and the figurative, between referential and non-referential dimensions of language, and between fact and fiction-and reinterprets them in terms of a continuum. I shall argue, however, that the main theses of metaphorical narrativism are dependent on the opposition of the literal and the figurative and the opposition of the facticity of literal and the "fictionality" of figurative uses of language, because these oppositions are presupposed in White's either-or argumentation. A continuum just won't do the job. Cf. Kansteiner, "White's Critique ofWriting of History," 
Consequently, epistemology and aesthetics trade places in philosophy of history as well: epistemology — up till then regarded as the bread and butter of analytical philosophy of history-is thrown out and aesthetics takes its place. ${ }^{15}$ I shall argue below that this is a consequence of the fact that narrativism also preserves a deep conceptual dichotomy, inherent in positivism, between "objective" empirical observation and "subjective" interpretation. Lingering behind these opposites is the classical contrast of foundationalism between episteme and doxa, as I hope to show.

The either-or logic just referred to can be seen at work in the way narrative is analyzed in metaphorical narrativism: either the narrative of the historian is a simple by-product of research, as the "traditional," positivistic view would have it, or it has nothing to do with research at all. Either the narratives of historians are empirically founded - as the "traditional," positivistic view would have itor historical narratives have no empirical foundations at all and are the product of literary imagination. Either language is transparent and referential vis-à-vis reality_as the "traditional," positivistic view would have it—or language is selfreferential and opaque.

The same logic of reversal can be seen at work in White's and Ankersmit's positions with regard to the truth-claim of narratives. Rejecting the view that the truth of narrative is the by-product of historical research, they simply negate the truth-claim of narrative altogether. This move should be resisted and criticized since the presupposition of the truth of historical narratives is crucial as long as we presuppose that history is a discipline and not a form of art.

By inverting empiricism, however, both White and Ankersmit have at the same time retained it instead of rejecting it. This inverted empiricism fulfills a crucial function in metaphorical narrativism because the plausibility of the fundamental theses on the fictionality of narrativity is completely dependent on its implicit contrast with empiricism. As Noël Carroll has argued, White's identification of all interpretation with imposition, imaginary construction, and literary invention presupposes the possibility of knowledge without interpretation-and that is

\footnotetext{
286, who also signals this problem in the later writings of White: "White's decision to introduce a more dialectical element into his structuralist methodology implies a renegotiation of the status of the fact with regard to the plot structures of the historical text. Once the strict separation of the two levels is canceled, his earlier radical epistemological relativism is undermined. The proposed continuum can be interpreted all the way towards the pole of factual accuracy. Thus the possibility of representational transparency, shown out the front door, returns through the back."

15. Ankersmit draws this conclusion explicitly with his introduction of the vocabulary of representation in the late 1980s. See Ankersmit, "Historical Representation," in History and Tropology, 102: "The suggestion [of the vocabulary of representation] is rather that the historian could meaningfully be compared to the painter representing a landscape, a person, and so on. The implication is, obviously, a plea for a rapprochement between philosophy of history and aesthetics." See also 105106 , where he identifies science with "codified representation" and restricts epistemology to this realm. Historical and artistic representation, however, are "indifferent to epistemology" according to Ankersmit. By retaining epistemology for the domain of science he is distancing his position from Rorty's. See his "Van theorie naar verhaal. Richard Rorty over taal en werkelijkheid," in De macht van representatie, 183-218.
} 
empiricism pure and simple. In the same spirit his argument that narratives qualitate qua are fictional-because they do not mirror the past in the way photographs and replicas do-presupposes an empiricist picture theory of knowledge and an empiricist theory of truth as direct correspondence. ${ }^{16}$ Carroll therefore is completely right to label White as a "closet empiricist," in thrall to a bad picture theory of language, but he does not fully recognize the crucial functions of empiricism in White's philosophical building: without empiricism there simply are no plausible arguments for the basic tenets of metaphorical narrativism. ${ }^{17}$

A similar criticism is applicable to Ankersmit's brand of metaphorical narrativism. Ankersmit too introduces the same remarkable, outdated, empiricist picture theory of knowledge as a contrast to his own position and in order to lend his metaphor theory plausibility and a philosophical profile. ${ }^{18}$ The same contrast is offered between narratives and replicas or mirrors in order to deny the former a cognitive status and to bridge the gap between history and literature. ${ }^{19}$ In his philosophy too a remarkable simplistic realism is introduced in order to discredit realistic interpretations of narratives altogether. ${ }^{20}$

16. See for instance White, "Historical Text as Literary Artifact," 88: "it is wrong to think of a history as a model similar to a scale model of an airplane or ship, a map, or a photograph. For we can check the adequacy of this latter kind of model by going and looking at the original and, by applying the necessary rules of translation, seeing in what respect the model has actually succeeded in reproducing aspects of the original." See further his "Interpretation in History," in Tropics of Discourse, 51, where he refers to "traditional" historians and their idea that they have to interpret their materials "in order to construct the moving pattern of images in which the form of the historical process is to be mirrored." See also his "The Question of Narrative in Contemporary Historical Theory," 27, on "traditional" historians: "The form of the discourse, the narrative, adds nothing to the content of the representation; rather it is a simulacrum of the content and processes of real events. And insofar as this representation resembles the events it represents, it is a mimesis of the story lived in some region of historical reality, and insofar as it is an accurate imitation, it is to be regarded a truthful account thereof" [my italics]. See also Carroll, "Interpretation, History and Narrative," 138-140, and Bernstein's fundamental critique of metaphysical realism alias objectivism. Bernstein's observation that this type of realism is "no live option" anymore hits the nail on the head. Therefore we should ask what functions this "dead" option fulfills in metaphorical narrativism. Cf. Bernstein, Beyond Objectivism and Relativism, 12.

17. Carroll, "Interpretation, History and Narrative," 147-148. I think Carroll's reference to the "empiricist residue" (147) in White is therefore incorrect.

18. Also in his later writings Ankersmit keeps identifying "scientific" language with "transparency" (alias "codified representation") in order to create a contrast with the nontransparency and "opaqueness" of historical language (alias "uncodified representation"). See for instance "History and Postmodernism" and "Historical Representation" in his History and Tropology.

19. Ankersmit, Narrative Logic, 91-92: "We cannot glimpse at history. We can only compare one book with another. ...We do not 'see' the past as it is, as we see a tree, a machine or a landscape as it is. We see the past only through a masquerade of narrative structures (while behind this masquerade there is nothing that has a narrative structure)." And 19: "Nearest to the narratio is the novel and amongst all kinds of novels it is, of course, the historical novel that comes closest to the narratio."

20. Ankersmit, Narrative Logic, 83: "[The narrative realist] regards the narratio as a kind of picture of the past: there is a controllable correspondence between photographs and pictures-taken as a whole as well as in detail—and that part of visible reality depicted by them. And it is believed that there is similar correspondence with the past. I shall call the adherents of this 'picture theory' narrative realists. Narrative idealism, on the other hand, rejects the picture theory." No wonder, following Ankersmit, even Popper ends up being labeled as a "scientific idealist." See Narrative Logic, 97. 
Empiricism also shows up in White's and Ankersmit's representation of historical research. Since they contrast narrative to research and defend an inverted empiricism for the level of narrative this was to be expected. In White's case empiricism can even be traced in his terminology when he refers to historical events as "elements" and to stories as "compositions" of these elements in his introduction to Metahistory. ${ }^{21}$ His wording in this context is important. He refers to events and not to facts; in this way he eschews the problem of interpretation at the level of research, because contrary to events facts have to be stated in factual statements. Since he identifies interpretation with narrativizing and fictionalizing this is the only way he can escape the tantalizing conclusion that facts are fictional. ${ }^{22}$ The "omission" of the problem of interpretation at the level of research in White's narrativism therefore is far from accidental. ${ }^{23}$

21. White, Metahistory, 5: "First the elements of the historical field are organized into a chronicle by the arrangement of the events to be dealt with in the temporal order of their occurrence; then the chronicle is organized into a story by the further arrangement of the events into the components of a 'spectacle' or process of happening, which is thought to possess a discernible beginning, middle, and end." In the same spirit he refers in a recent text to (archival) "information" concerning past events that has to be processed in "historical discourse" in order to become "historical." Cf. White, "Literary Theory and Historical Writing," 20, and Kansteiner, "White's Critique of the Writing of History," 284: "On the level of the single event/fact White retains an element of positivist stability which stands in contrast to the epistemological arbitrariness that he posits on the second level, the level of the conceptual framework of the historical writing."

White, however, keeps wavering on this issue, because later he sometimes resorts to an anti-positivistic, Nietzschean position. Cf. his "Fictions of Factual Representation," 127-128: "there is no such thing as a single correct description of anything, on the basis of which an interpretation of that thing can subsequently be brought to bear. . . All original descriptions of any field of phenomena are already interpretations of its structure. ..."

22. White sometimes comes close to admitting this paradoxical consequence of his position. See H. White, "A Rejoinder: A Response to Professor Chartier's Four Questions," Storia della Storiografia (Geschichte der Geschichtsschreibung) 27 (1995), 65: "One cannot transform a 'real' event, person, process, relationship, or what have you into a 'function' of a discourse without 'fictionalizing' it, by which I mean 'figurating' it. The translation of the stuff of reality into the stuff of discourse is a fictionalizing." In "Literary Theory and Historical Writing" White, however, explicitly denies that he obliterates the distinction between fact and fiction, although it is not clear on what grounds (35). Now he defends tropological analysis to the point of almost equating it with an epistemological position one could derive from E. H. Carr's What is History? In the same move, however, the emphasis is now shifted from the fictionality of figuration to its factuality, thus adding to the existing ambiguity in this matter: "If there is no such thing as 'raw facts,' but only events under different descriptions, then factuality becomes a matter descriptive protocols used to transform events into facts. Figurative descriptions of real events are not less 'factual'-or, as I would put it, 'factological'-in a different way. Tropological theory implies that we must not confuse 'facts' with 'events.", "Who would confuse them in 1990?" seems to me a legitimate question.

For criticism of this type of use of the term "fiction" cf. Ann Rigney, "Semantic Slides: History and the Concept of Fiction," in History Making: The Intellectual and Social Formation of a Discipline, ed. R. Thorstendahl and I. Veit-Brause (Stockholm, 1996), 31-47.

23. In "Literary Theory and Historical Writing" White states on 20: "Historical discourse does not, then, produce new information about the past, since the possession of both old and new information about the past is a precondition of the composition of such a discourse. Nor can it be said to provide new knowledge about the past insofar as knowledge is conceived to be a product of a distinctive method of inquiry. What historical discourse produces are interpretations of whatever information about and knowledge of the past the historian commands." On 21 he explicitly characterizes "historical discourse as interpretation and historical interpretation as narrativization." In "Interpretation in 
In Ankersmit's case too empiricism lurks in his representation of historical research. After elaborating on the similar status of scientific theories and historical narratives, he halts the train at the same station as White does and probably for the same reasons: he simply asserts that the "theory-ladenness of empirical facts" does not apply to historical facts . . because "historians always use a-theoretical, ordinary language." ${ }^{24}$ An empiricist representation of historical research thus turns out to represent the epistemological flipside of a metaphorical representation of the historical narrative. In its zeal to redress the "traditional" identification of professional history with the application of research methods and in its neglect of history writing, metaphorical narrativism ends up omitting historical research altogether from the discipline's identifying characteristics. ${ }^{25}$

\section{NARRATIVISM AS INVERTED POSITIVISM (2): \\ NARRATIVISM AS AN INVERSION OF THE COVERING-LAW VIEW OF EXPLANATION}

The first consequence of the "metaphorical turn" from an explanatory point of view is the most important one, namely, the narratio is born as a linguistic entity independent of the individual statements it contains. ${ }^{26}$ The claim that these narratios at the same time constitute the explanations of what is described by their statements is a break with - and reversal of - the covering-law view of explanation. Ankersmit's arguments on this issue are more explicit than White's and therefore I will first analyze his line of reasoning.

Ankersmit's claim that narratives are self-explanatory, just as metaphors are, is founded on his characterization of historical interpretations-labeled by him as narrative substances or "Nss" - as self-referential. This somewhat paradoxical characteristic follows from the conceptual strategy I signaled before, that is, the separation of history writing from historical research. Historical research, ideally, produces true singular, descriptive statements which refer to past reality, and historical narratives consist of collections of those statements. Far more important to Ankersmit is the point-of-view function of narratives, which is the product of the way the historian organizes the descriptive true statements into a narrative whole or Ns. Every Ns is defined by the sum total of these singular

History," 58-59, White shuns the problem of interpretation at the level of research in the ambiguous statement that "there are at least [my italics] two levels of interpretation in every historical work: one in which the historian constitutes a story out of the chronicle of events and another in which, by a more fundamental narrative technique, he progressively identifies the kind of story he is telling-comedy, tragedy, romance, epic, or satire, as the case might be." Cf. Alex Callinicos, Theories and Narratives: Reflections on the Philosophy of History (Cambridge, Eng., 1995), 76-78.

24. Ankersmit, Narrative Logic, 230-231.

25. It should be noted that Ankersmit acknowledges the complementarity of the philosophy of historical narrative and the philosophy of historical research, but he remains silent about their relationship. Cf. Ankersmit, Narrative Logic, 6-9, and his History and Tropology, 2-6.

26. See, however, Gorman's critique of Ankersmit's textual holism in J. Gorman, "Philosophical Fascination with Whole Historical Texts," review of Ankersmit's History and Tropology, in History and Theory 36 (1997), 406-415. 
statements: altering one statement would yield a different Ns. Therefore every singular statement contained by a Ns is a logical property of the Ns because it is necessary for its identity. Therefore the narrativist universe is basically identical to the universe of Leibniz's monads, in which a logical — and thus necessaryharmony reigns supreme: narratives in their point-of-view capacity cannot contradict one another, according to Ankersmit, but can only be different. The unique identity that the proponents of classical Historismus mistakenly attributed to historical reality itself therefore should be attributed to historical narratives, so Ankersmit argues.

Ankersmit's next and crucial move is the deduction of an explanatory necessity from the logical necessity in the narrativistic_linguistic_- universe: "Thus, when the past (i.e. not Nss) is described in terms (of the narrative statements) of Nss, we can say that the past has been explained, because the Nss embodying such an explanation could not have been different. The explanandum (i.e. what falls within the scope of a Ns) is explained by what defines the narratio's scope (i.e. the statements contained in a narratio)." ${ }^{27}$ "Now we know what was the cause of the échec of the Covering Law Model: a set of singular statements may be sufficient to give a historical explanation." 28

Along with empirical laws Ankersmit's narrativism eliminates the principle of causality from its explanatory logic: "Historical understanding is achieved by describing the past with the help of a strong and vigorous Ns and not by the discovery of causal relationships." ${ }^{29}$ While Positivism held "No causes, no explanation," Ankersmit's narrativism claims the exact opposite: whatever the explanatory links of historians are, they are not causal! (But as with Positivism, Ankersmit presupposes that in history there is just one explanatory model.) After living for more than two centuries under Hume's spell, narrative historians can finally breathe freely.

In White's narrativism we encounter a quite different and more illicit inversion of Positivism than in Ankersmit's. White's concept of explanation is not monistic, but multilayered; and it definitely lacks the formal rigor of Positivism and of Ankersmit's logical analysis. Next to the three types of explanation related to narratives as wholes that form the core of his philosophy - the explanation by formal argument, by ideological implication, and by emplotment-he mentions explanations in narratives without identifying them any further. He acknowledges that "certain narrative discourses may have arguments embedded within them, in the form of explanations of why things happened as they did." ${ }^{30}$ But

27. Ankersmit, Narrative Logic, 245.

28. Ibid., 246. White's position with regard to lawlike explanation is different from Ankersmit's because he acknowledges that some ("mechanicist") historians do explain by referring to presumed laws. He, however, also rejects the positivist claim that subsuming an event under a law is a necessary condition for historical explanation. Cf. his Metahistory, 11-22.

29. Ankersmit, Narrative Logic, 163.

30. White, "The Question of Narrative in Contemporary Historical Theory," 43. Cf. White, Metahistory, 7, where he makes the distinction between "synoptic judgments" concerning narratives as structures of complete sets of events, and judgments at a lower level concerning the relations between singular events. 
according to White these explanations do not belong to the narrative proper but only to the chronicle, that is, the type of order that events possess before they are properly "narrativized" by the historian. ${ }^{31}$ To all appearances White incorporates this level of explanation in the phase of research and this could explain why any further analysis is missing.

The same holds for the striking fact that in White's philosophy there's no connection whatsoever between these explanations belonging to the level of chronicle and White's three types of narrative explanation. Elucidating what types of relationships we encounter in history he consequently restricts his analysis to narrative relationships localized - in a surprisingly Collingwoodian spirit - in the historian's mind: "Histories, then, are not only about events but also about the possible sets of relationships that those events can be demonstrated to figure. These sets of relationships are not, however, immanent in the events themselves; they exist only in the mind of the historian reflecting on them." ${ }^{32}$ Just like Ankersmit's, White's narrativism too is susceptible to a strong pull of idealism. ${ }^{33}$

As is well known, White's threefold schematization of quadripartite explanatory strategies results in twelve explanatory combinations. But because he does not claim that his scheme is exhaustive of explanatory practices in history there might be many more. ${ }^{34}$ So Paul Ricoeur hits the nail on the head in remarking that White's narrativism in the end leads to a "tropological inflation" that may be interpreted as another way of inverting the covering-law model of explanation. Instead of instructing historians how to follow The Path of Real Science, White instructs them that all striving for scientific explanation and foundation is futile, because all they will achieve in the end is self-created linguistic constructions imposed on a chaos of (archival) "information." 35

31. White, "The Question of Narrative in Contemporary Historical Theory," 45: "But such assessments [explanations] touch only that aspect of the historical discourse conventionally called its chronicle. It does not provide us with any way of assessing the content of narrative itself." As Callinicos has stressed, White wavers between the idea that events present themselves to the historian in a completely unstructured, chaotic form before they are "narrativized" and the idea that they present themselves in their temporal order, as a chronicle. Cf. Callinicos, Theories and Narratives, 74-75.

32. White, "Historical Text as Literary Artifact," 94. Cf. Ankersmit, Narrative Logic, 117 on narrative substances: "Nss function only at the level of words" and therefore are non-referential.

33. In History and Tropology, 107, Ankersmit claims that the vocabulary of representation is "beyond" the problem of realism versus idealism and that this problem is only created by and in epistemology. Implicitly he thus rejects "narrative idealism" as developed originally in Narrative Logic: "The inestimable positive achievement of epistemology has been to create in the transcendental ego the indispensable platform that is a prerequisite for all science. Its limitation, however, has been that in attributing all cognitive primacy to the transcendental ego it has effected the melting away of both reality itself and the representation in art and history. Epistemology has thus created the unpleasant dilemma of having to choose between a realistic and an idealistic interpretation of scientific knowledge. Moreover, the representation of reality by the individual cognitive subject that is not reducible to a transcendental ego has since been seen as a doubtful enterprise from a cognitive point of view." The "price" Ankersmit is paying for placing metaphorical narrativism "beyond" the dichotomy of realism versus idealism, therefore, is placing it "beyond" epistemology.

34. Cf. Carroll, "Interpretation, History and Narrative," 141-143.

35. Ricoeur, "Geschichte und Rhetorik," 121. Another remnant of Positivism may be located in White's monistic presupposition that every historical narrative is "explained" by just one plot structure. McCullagh's objections in this case seem legitimate. See C. Behan McCullagh, The Truth of 
With Paul Roth one can even doubt whether White's narrativism is more than a psychology of explanation (or a classificatory scheme), and whether it contains any logic of explanation at all. Let's take his explanation by emplotment for example, because White seems to regard this as historical explanation par excellence. He expounds this type of explanation in the following passage: "Providing the 'meaning' of a story by identifying the kind of story that has been told is called explanation by emplotment. If, in the course of narrating his story, the historian provides it with the plot structure of a Tragedy, he has 'explained' it in one way; if he has structured it as a Comedy, he has 'explained' it in another way. Emplotment is the way by which a sequence of events fashioned into a story is gradually revealed to be story of a particular kind." ${ }^{36}$ Emplotment in historical discourse according to White owes its "explanatory effect" to the recognition by the reader of the meaning conferred upon the text by the historian. ${ }^{37}$ But in what way recognition of culturally shared plot structures and tropes can be considered as explanatory is neither evident nor argued for by White. ${ }^{38} \mathrm{An}$ argument is surely needed, if only because White's views on explanation by metaphor and emplotment are contradicted by some leading representatives of "traditional" history, such as G. R. Elton. In a review of a book by Emmanuel Le Roy Ladurie Elton remarks that the author "believes that metaphors and similes explain things, while in fact they provide only evidence that an explanation has been avoided. No historian should think that he has made a point when he compares the expanding populations of Europe to an exploding galaxy, or describes the social structure of a village to a magnetic field." ${ }^{39}$ So to all appearances White does have a problem here, because a similar argument can be made regarding explanation by emplotment.

\section{HISTORICAL EXPLANATION AS A LINGUISTIC OPERATION}

Now that we have analyzed metaphorical narrativism as the result of a twofold inversion of positivism, it is time to analyze how both inversions are interrelated and what the consequences are for the logic of narrativistic explanation. If my

History (London and New York, 1998), 127: "As a whole, the French revolution and the life of J. F. Kennedy is neither a romance nor clearly a tragedy. Because an interpretation of these events is meant to characterize them as a whole, neither plot is appropriate."

36. White, Metahistory, 7.

37. Cf. White, "Historical Text as Literary Artifact," 99: "In my view, we experience the "fictionalization' of history as an 'explanation' for the same reason that we experience great fiction as an illumination of a world we inhabit along with the author. In both we recognize the forms by which consciousness both constitutes and colonizes the world it seeks to inhabit comfortably."

38. Cf. Paul Roth, "How Narratives Explain," Social Research 56 (1989), 460: "White's concern is not logical but typological," and 461: "White has title to being called, perhaps, the Linnaeus of narrative explanation. However, his typology reveals nothing with regard to explanatory logic; about what makes a story type an explanation White has nothing to say." See also Roth, "Narrative Explanations," 1-13.

39. G. R. Elton, Review of E. Le Roy Ladurie, The Mind and Method of the Historian, London Review of Books 18 (1981), 3, 8. 
thesis of a "hidden empiricism" in White's and Ankersmit's representation of historical research is correct, and if I am also correct that their conceptions of metaphorical explanation are developed in direct contrast with this "hidden empiricism' - and therefore are dependent on it — then we can easily understand why metaphorical explanation is conceived as purely linguistic and why narrativism provides no connection between metaphorical explanation and factual research.

White represents the most serious case in this respect because he explicitly and frequently contrasts knowledge to interpretation when he identifies interpretation with narrativizing and "fictionalizing." This contrast harks back to the classical opposition of epistemology to hermeneutics, which is again derived from the classical opposition between episteme and doxa. As Tom Rockmore pointed out in relation to Gadamer's hermeneutics, this classical opposition denies interpretation the status of a scientific cognitive operation and restricts it to subjective conviction. And as he points out, this opposition presupposes in its turn the classical identification of knowledge with founded, "absolute" knowledge. ${ }^{40}$ This basic conceptual opposition in White's metaphorical narrativism leads to his abandonment of epistemology and rationality. Because White presupposes that narrative, interpretive strategies are non-cognitive, the choice between different narrative explanations cannot be related to factual arguments and be rational. Explanation according to White, therefore, must be a purely linguistic operation, guided by aesthetic or moral criteria: otherwise the epistemological problem of representational adequacy would return to haunt White's agenda. Thus, it is not accidental that his narrativism does not contain any epistemological criteria other than truth in its correspondence sense. For if a relationship between the narrative and factual levels were established, White's narrativism-at least in its original form-would face major inconsistencies. ${ }^{41}$

In the end the fundamental problem with White's narrativism consists of its continuing implicit alliance to foundationalism and its inseparable companion, skepticism (skepticism because arbitrariness presents itself as the only alternative

40. T. Rockmore, "Epistemology as Hermeneutics," The Monist 73 (1990), 116.

41. White, Metahistory, xii, 4, 20, 26. For White's problems in this case, see the conclusion of the present article and Kansteiner in note 14. For the absence of epistemological criteria other than "truth," see Carroll, "Interpretation, History and Narrative," 160-161: "To be an adequate narrative, indeed to be an adequate historical account of any sort, a candidate needs to do more than merely state the truth (indeed, an historical account could contain only true statements and be judged unacceptable). It must also meet various standards of objectivity." "Like any other cognitive enterprise, historical narration will be assessed in terms of rational standards which, though they are endorsed because they appear to be reliable guides to the truth, are not reducible to the standard of truth." White overlooks the possibility of objective standards-like comprehensiveness - that are "truthtracking": "Thus, in evaluating the selections and deletions the narrative historian makes, we need not feel that we must embrace some special standard of truth, like metaphorical truth. Rather, our concern with historical narratives is that they be true in the ordinary sense of truth and that our assessments of their adequacy in terms of standards like comprehensiveness are keyed to determining truth." Cf. McCullagh on elucidation of truth and fairness as criteria for historical knowledge in his The Truth of History, 13-62. 
to knowledge based on a firm foundation). ${ }^{42}$ Seen in that light it is not so strange that White's concept of interpretation manifests a striking similarity to the "traditional" concept of interpretation he set out to combat: in both concepts, empirically founded knowledge and interpretation appear as opposites. ${ }^{43}$ This is the inevitable consequence of linking both knowledge and rationality exclusively to nonexisting infallible foundations of knowledge (such as truth in the picturetheory sense). (As I will show shortly, as soon as we enter the world of real narratives, however, we only encounter fallible and competing knowledge claimsand this holds for individual statements as well as for narratives as wholes.)

Ankersmit travels a similar trajectory as White and ends up with similar problems. He too constructs an opposition between knowledge and interpretation while absorbing interpretation in aesthetics. ${ }^{44}$ Therefore it is not accidental that Ankersmit's narrativism exhibits a similar problem as White's, though with considerable differences. Also in his case the explanatory power of narratives is conceptualized on the linguistic level since Nss are purely linguistic instruments. This means that narrative explanation is conceptualized as an interrelationship between statements and not as a relationship between statements and reality. ${ }^{45}$ And because statements can be interrelated in many different ways, there is always a plurality of narrative explanations of the same set of factual statements. Of course, the covering-law model of explanation is also formal, because it states the formal criteria that must be satisfied for an argument to count as a scientific explanation. However, the empirical adequacy of this formal model of explanation is guaranteed because its explanans contains an empirical law, from which the explanandum is logically deduced (in combination with the statements of initial conditions). By means of a causal mechanism the formal model is anchored in empirical reality, so to speak (at least in covering-law theory). ${ }^{46}$ In the case of

42. White's critique of "empiricism" recently has been elevated to the agenda of a new journal, Rethinking History (first issue, Spring 1997). Refuting "empiricism" in history is becoming a booming industry. See the "Editorial" in the first issue by Alan Munslow; Keith Jenkins, "Introduction: On Being Open about Our Closures," in The Postmodern History Reader, ed. Keith Jenkins (London and New York, 1997), 1-36; and K. Jenkins, On "What is History?": From Carr and Elton to Rorty and White (London and New York, 1995).

43. Cf. White, "Interpretation in History," 55, where he describes his competitors in philosophy of history as theorists who grant that "interpretation may enter into the historian's account of the past at some point and recommend that historians try to distinguish between those aspects of their accounts that are empirically founded and those based on interpretative strategies."

44. See note 5. With regard to the relationship of hermeneutics - and thus interpretation - to aesthetics, Ankersmit distances his position clearly from Gadamer's. See his "Historical Representation," 102: "Meaning has two components: the world, and the insight that it can be represented in a certain way, that it can be seen from a certain point of view. We must therefore disagree with the hierarchical order of representation and hermeneutics when he [Gadamer] writes that 'aesthetics has to be absorbed into hermeneutics.' The reverse is in fact true: aesthetics, as the philosophy of representation, precedes that of interpretation and is the basis for explaining interpretation."

45. Ankersmit's comparison of history with a natural science that only disposes of (formal) mathematics and not of (empirical) experimental means to test the adequacy of its theories brings the same point home. Cf. his "De activiteit van de historicus," in Hermeneutiek en cultuur. Interpretatie in de kunst- en cultuurwetenschappen, ed. F. R. Ankersmit et al. (Meppel and Amsterdam, 1995), 94-95.

46. There is no need here to question the status of the covering-law model itself nor its relationship to the discipline of history, because my only point is its relationship to the metaphorical model 
Ankersmit's formal model of narrative explanation such a guarantee of the empirical adequacy of narrative explanation is missing, because according to this model any set of (true) descriptive, singular existential statements is explanatory at the same time. He fails, however, to spell out why he believes this is so. After all, it is not difficult to imagine a collection of true descriptive statements that do not explain at all; as a matter of fact, this often is the case. His jump from a logical necessity in the universe of Nss to an explanatory necessity in the universe of narratives thus turns out to be a salto mortale. Therefore it comes as no surprise that the historiographical universe does not display the harmony of Ankersmit's narrativistic universe: not only do historical narratives lack their presumed necessary self-explanatory property, but they also regularly contradict each other instead of just being different. This feature explains why historians normally feel the need to discuss various narratives on the same topic and to invest so much energy in answering the question as to which narratives are empirically adequate. If historical narratives would just represent different and closed linguistic universes and not empirically justifiable truth-claims, the fact of historical debate would remain incomprehensible. The relationship between real narratives and Nss therefore remains an unsolved problem in Ankersmit's narrativism.

Now, although a plurality of explanations itself is not a problem, a plurality of narrative explanations conceived in a Whitean or Ankersmitian way is because this plurality is not restrained by empirical criteria. Therefore anything seems to go in the narrativistic universe, just as long as the individual descriptive statements are true. The abandonment by metaphorical narrativism of the monistic and foundationalist ideals of the covering-law theory of explanation thus has resulted in its reversal: embracing an unlimited variety of empirically undecidable narrative explanations and the replacement of epistemological by aesthetic criteria. ${ }^{47}$ Here again we see the fatal workings of the logic of reversal. As a consequence of this unfettered "artistic" freedom of historians from factual constraints, both White's and Ankersmit's conceptions of narrative explanation are seriously infected with subjectivism, which leads to a strained relationship between metaphorical narrativism and the practice of history. ${ }^{48}$ Therefore we

of explanation. For an overview of the debate on covering-law theory, see W. Salmon, Four Decades of Scientific Explanation (Minneapolis, 1990). For the problematic relationship between covering-law theory and history, see my Konstruktion der Vergangenheit, chapters 9 and 10.

47. With respect to criteria for the evaluation of narratives there are significant changes in Ankersmit's position over time. In Narrative Logic, 239-261, he suggests the applicability of the Popperian epistemological criterion "scope" to decide which narrative of a competing set is most adequate, although he fails to regard this criterion as "truth-tracking" (because narratives in his opinion cannot be true). From his conversion to postmodernism onwards - around 1985-and his adoption of the vocabulary of "representation" he renounces epistemology as far as history is concerned in favor of aesthetics. In a recently (1996) published article "De rationaliteit van de geschiedbeoefening" (The Rationality of History), published in Ankersmit, De spiegel van het verleden, 59-96, Ankersmit seems to return to a modest rehabilitation of epistemology in history.

48. Cf. Kansteiner, "White's Critique of the Writing of History," on White's original position: "Thus White strives to sever any link between the reality of past events and their semantic position in the historiographical text." Later White changed this position leading to the signaled contradictions. 
cannot regard metaphorical philosophy of history as an adequate analysis of historical practice. The best we can do is try to learn from its mistakes and to analyze where its subjectivistic drift stems from. This observation leads me to my conclusion.

\section{CONCLUSION}

I have argued that the subjectivistic drift of metaphorical narrative philosophy can be explained by its reversal of the two brands of positivism I identified earlier on, the positivism of facts and the positivism of covering-law explanation. As both forms of positivism were derived from the dominant image of natural science, metaphorical narrativism owes its fundamental characteristics to its reversal of the nineteenth-century natural science model. So in a sense the ghosts of Hume, Comte, and Hempel still haunt philosophy of history, albeit in a negative shape. As I have argued, the attack on both flanks of positivism helps to explain the fundamental traits of metaphorical narrativism and especially its drift towards fictionalism and towards the mistaken parallelism of history and literature. For although metaphorical narrativism surely deserves credit for the (re)discovery that historians produce texts and that history therefore possesses textual aspects, it is equally mistaken in its essential identification of history with its textual qualities (although White is not entirely consistent on this score given his critique of textualism in Foucault and Derrida) ${ }^{49}$ This is so because of a trivial but fundamental fact, namely, that history, contrary to all fictional literature, is always about something outside the text-the real past. This referential quality of historical narratives explains why the construction of narratives about the past is an activity with disciplinary, intersubjective controls, because the ways in which we refer with words to things are intersubjective. The fact that reference is not selfevident cannot be regarded as an argument contra the referential quality of language because reference is never a simple given. ${ }^{50}$ If this were to count as an argument one could on the same grounds argue against the reference of individual statements - in history as well as all empirical sciences (a position not even White or Ankersmit supports).

The same applies for the notion of truth, for the idea that the truth of individual statements - in contrast to the truth of a narrative-is self-evident and beyond debate, as picture theories of knowledge suggest, cannot be upheld. At both levels the establishment of truth and falsity is dependent on fallible, intersubjective conventions; the difference between individual statements and complete narra-

49. Cf. White, "The Absurdist Moment in Contemporary Literary Theory," in Tropics of Discourse, 261-183. Cf. Kramer, "Literature, Criticism and Imagination, 97-128.

50. White's introduction in "Question of Narrative in Contemporary Historical Theory," 43, of a distinction between a "primary" and a "secondary" referent of narratives is a failed attempt to avoid the self-created problem of reference. The "primary" referent would consist of the past itself, the "secondary" of the "the plot structures of the various story types cultivated in a given culture." The real problem is of course the referential relationship between narratives and the past, that is, the relationship between the "primary" and "secondary" referent. 
tives is therefore a difference in degree and not in kind. ${ }^{51}$ But, as stated earlier, truth by itself is - contrary to what White and Ankersmit suggest on the basis of their picture theory of knowledge — not a very exciting epistemological criterion, although it is a constitutive value for cognitive activity as such. This is the consequence of the fact that since episteme proved to be a false ideal, its distinction with doxa has evaporated, and fallibilistic truth-theories have taken the place of foundationalism and its picture theories of truth. This means that since Popper's Logik der Forschung in 1934 epistemology has exchanged its interest in direct truth-criteria for criteria to assess the relative quality of claims to truth alias knowledge claims (in the form of theories, research-programs, paradigms, or narratives). With this goal epistemology has developed truth-tracking criteria-to use Carroll's apt phrase—such as scope, explanatory power, comprehensiveness, and so on and these are the criteria that really matter whenever we want to assess rival knowledge claims. Being true means something rather trivial like "in accordance with the known facts and not (yet) falsified," but truth in this sense is merely a necessary and not a sufficient condition for cognitive quality. ${ }^{52}$ This applies to individual statements as well as to complete narratives and theories.

Neither at the level of individual descriptive statements nor at the level of the narrative organization of those statements is it possible to disentangle the referential, descriptive from the metaphorical, point-of-view function, because all linguistic representations of reality at the same time constitute points of view at reality, recognized as such or not. The singular descriptive statements "In 1997 freedom fighters in Zaire succeeded in ending Mobutu's corrupt dictatorship" and "In 1997 rebels in Zaire succeeded in overthrowing president Mobutu's legitimate government" both carry points of view, just as would complete narratives on the subject. At both levels it is not the presence or absence (the either-or) of a point of view that matters - there is no view from nowhere in both cases. Both White and Ankersmit seem to hold that the points of view at the level of singular descriptive statements are uncontestable and that the opposite is the case at the level of total narratives. Their argument that the notion of truth only applies to individual descriptive statements follows directly from this presupposition. They fail to adduce any argument, however, why we should follow this, by now familiar, either-or scheme. Again, as long as there are differences in this respect between statements and narratives, these differences are in degree and not in kind. ${ }^{53}$

51. The identification of conventional and arbitrary, often encountered in postmodernist circles, should be resisted by all means-unless one is prepared to label all of natural science as arbitrary. As Popper pointed out in 1934, even the acceptance of the most elementary observational statements (Protokol- or Basissätze) requires conventional decisions by the scientific community. See Criticism and the Growth of Knowledge, ed. I. Lakatos and A. Musgrave (Cambridge, Eng., 1970), esp. 102116 for the discussion on conventionalism in natural science in relation to the debate on Thomas Kuhn's Structure of Scientific Revolutions.

52. Cf. Nelson Goodman, Ways of Worldmaking (Indianapolis, 1978), 18: "Truth, far from being a solemn and severe master, is a docile and obedient servant. The scientist who supposes that he is single-mindedly dedicated to the search for truth deceives himself. He is unconcerned with the trivial truths he could grind out endlessly; and he looks to the multifaceted and irregular results of observations for little more than suggestions of overall structures and significant generalizations. He seeks system, simplicity, scope; and when satisfied on these scores he tailors truth to fit."

53. McCullagh argues along similar lines regarding the truth conditions of metaphorical language. See his The Truth of History, 62-82. 
The complexity of the notion of truth in the case of narratives (or scientific theories) cannot be used as an argument against it, for as long as we presuppose that historical narratives refer to a real past and thus represent knowledge of the past, historical narratives constitute truth-claims that must be elucidated and not annihilated by philosophy of history. ${ }^{54}$ How these claims are justified in practice is another problem that need not bother us here because the meaning and the establishment of truth are distinct problems. This holds for individual statements as well as for narratives.

The importance of the intersubjective character of the rules of "doing history" in contrast to "doing literature" cannot be overemphasized because it constitutes history's distinguishing hallmark as an empirical discipline. In contrast to authors of fiction, historians deal with an object and with definitions of the object that are open to public scrutiny and debate. And so is the evidence they use to back up their arguments, because as a consequence of the public character of history historical narratives cannot just be presented, as are their fictional counterparts, but they stand in need of constant empirical and logical backing. ${ }^{55}$ These characteristics are manifest in the old habit of historians, contrary to all authors of fiction, of criticizing one another for the empirical and conceptual inadequacies of their stories as a whole and not just for the individual statements narratives contain. In the recent debate on Goldhagen's Hitler's Willing Executioners, for instance, one problem is the adequacy of the point of view embodied in his narrative rather than merely the truth of the individual statements.

It is the rule-governed character of history that makes it an intersubjective enterprise, as the former narrativist Lionel Gossman has emphasized: "Historians do apparently believe that there are procedures of verification and criteria for judging between different hypotheses and narratives." "Modern historiography, like modern science, is a professionalized and regulated activity in which no individual can any longer imagine that he or she works alone or enjoys a special relationship to the past. In this respect it differs from neoclassical or Romantic historiography." ${ }^{56}$ (It is not accidental that many postmodernists regard Romantic historiography as the paradigm of all history writing. $)^{57}$

It is this permanent necessity of argument (as a consequence of historical narratives' truth-claims) that explains why there is such a thing as historical debate which keeps the motor of history as a discipline running. And this is where the rationality of history can be localized, as Lionel Gossman, Allan Megill, and

54. In this respect David Cooper's remarks on metaphor and truth are important. Cooper criticizes those theories of metaphor and truth that fail to elucidate why truth is a fundamental value guiding our cognitive activities. See his "Truth and Metaphor," in Knowledge and Language, ed. Ankersmit and Mooij, 37-49.

55. This aspect of history is also stressed by Megill, "Recounting the Past."

56. Cf. L. Gossman, "The Rationality of History," in Between History and Literature, 313, 315. See also 309: "The way historians communicate with each other and criticize each other's work suggests that they indeed expect their colleagues to be able to recognize the force of contrary arguments and narratives to adjust their own accordingly - either by developing answers to these arguments or by revising their own." See also A. Megill and D. McCloskey, "The Rhetoric of History," in The Rhetoric of the Human Sciences: Language and Argument in Scholarship and Public affairs, ed. J. Nelson, A. Megill and D. McCloskey (Madison, 1987), 228, 235.

57. Cf. my Konstruktion der Vergangenheit, 177-187, and F. R. Ankersmit, "The Origins of Postmodernist Historiography," in Historiography between Modernism and Postmodernism, ed. J. Topolski (Amsterdam and Atlanta, 1994), 107-119. 
Paul Ricoeur also have emphasized recently. ${ }^{58}$ So if history is characterized by its narrative form alone one disregards the fuel of its motor: historians don't claim to present just a story but a true story, and this truth-claim is its distinguishing hallmark. The basic problem with metaphorical narrativism as a philosophy of history is that it does not account for this difference, although of course it acknowledges the truth-claim of the individual statements contained in a historical story.

In the end this neglect can be traced back to the inability of metaphorical narrativism to connect history writing with historical research. Both White and Ankersmit disconnect, as we observed, the referential, descriptive, or literal content of metaphors and the non-referential or figurative content of metaphors; and both authors identify the construction of narrative exclusively with the non-referential aspects. As a consequence of this split the problems of truth and reference are relegated solely to the phase of research while the problem of the relationship between research and narrative disappears in a philosophical black hole. ${ }^{59}$

The disappearance of the relationship between research and narrative is in my opinion fatal for any philosophy of history, since the dynamics of history can only be found in the relationship between research and narrative. ${ }^{60}$ Otherwise why would historians bother about research at all? ${ }^{61}$ Therefore, it is significant that in a confrontation between White's narrativism and practicing historians-a confrontation arising out of the historiography of the Holocaust-White's theory got into very serious problems. Many of White's crucial distinctions, such as the distinction between chronicle and narrative and between "non-narrativized" events in research and their later "narrativization" in history writing, were severely criticized by historians such as Christopher Browning, Martin Jay, and Carlo Ginzburg. ${ }^{62}$ White's narrativism is built on two distinctions that do not show up

58. Cf. note 56. For Ricoeur see his "Geschichte und Rhetorik."

59. The restoration of this relationship is also Ricoeur's main objective in "Geschichte und Rhetorik." He concludes that the connection between the two components of classical rhetoric-the theory of argumentation and the theory of tropes - is dissected by White. By identifying history writing only with tropology White turns a blind eye on its argumentative foundations and its relationship with the research of past reality and search for truth. As a result history writing is cut loose from epistemology and ultimately dissolves in the tropological half of rhetoric. Ricoeur therefore pleads for a systematic connection between both components of classical rhetoric and a rehabilitation of the epistemological dimensions of history.

60. I have analyzed this relationship and the dynamics of a historiographical discussion in "Beyond Good and Evil? The German Empire of 1871 and Modern German Historiography," Journal of Contemporary History 30 (1995), 729-765.

61. Ankersmit, "History and Postmodernism," 172, comes close to denying the role of research in postmodernist history by completely dissolving history in the interpretation of other interpretations: "The modernist historian follows a line of reasoning from his sources and evidence to an historical reality hidden behind the sources. On the other hand, in the postmodernist view, evidence does not point towards the past but to other interpretations of the past; for that is what we in fact use evidence for. To express this by means of imagery: for the modernist, the evidence is a tile which he picks up to see what is underneath it; for the postmodernist, on the other hand, it is a tile which he steps on in order to move on to other tiles: horizontality instead of verticality."

62. I am referring to their essays in Probing the Limits of Representation: Nazism and the "Final Solution," ed. S. Friedländer (Cambridge, Mass., 1992). See C. Browning, "German Memory, 
in the practice of history: first, a distinction between literal and figurative language, and, second, the exclusive use of literal language during the phase of research and the use of figurative language — read metaphor_during the phase of composition or writing. The same distinctions and presuppositions are, as we observed, crucial for Ankersmit's narrativism.

As a result of these criticisms White was forced to drop-almost silently but most significantly - the basic tenet of metaphorical narrativism: the presupposition that all historical narratives can be emplotted at will by the historian because emplotment is not restrained by empirical constraints: "In the case of an emplotment of the events of the Third Reich in a 'comic' or 'pastoral' mode, we would be eminently justified in appealing to 'the facts' in order to dismiss it from the list of 'competing narratives' of the Third Reich." ${ }^{3}$ But if the "freedom of emplotment" thesis is given up, so must the thesis that narratives-just like metaphors-are necessarily explanatory, regardless of the facts - the other basic tenet of "metaphorical" narrativism. ${ }^{64}$ If the Third Reich cannot be emplotted at will because of the facts, then the explanation by emplotment is also restricted by the facts.

The "metaphorical turn" as formulated by White and Ankersmit is therefore inadequate as philosophy of history and should be replaced by analyses that suit the practice of history better. Such analyses should acknowledge the metaphorical or theoretical aspects in both research and narrative and should use a notion of metaphor that does not preclude metaphorical statements being true or untrue. Such analyses of metaphor exist and are elaborated by, for instance, Mary Hesse and Lakoff and Johnson. ${ }^{65}$ According to these authors all use of language is fun-

Judicial Interrogation, and Historicial Reconstruction: Writing Perpetrator History from Postwar Testimony," in Probing the Limits, ed. Friedländer, 29-32: "As historians have increasingly recognized over the past half-century, there is no clean distinction between 'facts' and 'interpretation,' in which the latter emerges as self-evident or is constructed out of the undisputed raw materials of the former." "For the history of one day in Jozefow, as for all history, virtually every 'fact' was an act of interpretation in itself, which is to say that it resulted from a judgment of the historian." "Although I would not disagree that it is the plot that determines the narrative, I would add that the questions being posed shape the plot and narrative together." "In my view there are no distinct and separate categories of attestable fact on the one hand and pure interpretation on the other. Rather there is a spectrum or a continuum." Cf. also M. Jay, "Of Plots, Witnesses and Judgments," in Probing the Limits, ed. Friedländer, 105: "Another consideration also militates against the unfettered freedom of historians to narrativize arbitrarily, and this concerns the community of others that reads and judges their work." "It is not so much the subjective imposition of meaning, but rather the intersubjective judgment of meanings that matters." See also Kansteiner, "White's Critique of the Writing of History," 290-293.

63. White, "Historical Emplotment and the Problem of Truth," in Probing the Limits, ed. Friedländer, 40.

64. In "Historical Text as Literary Artifact," 85, White has significantly "softened up" his original position without giving it up: "The important point is that most [my italics] historical sequences can be emplotted in a number of different ways. . .." Ankersmit's argument concerning the explanatory power of narratives runs into similar problems as White's. On the one hand Ankersmit claims that every Ns is explanatory by definition, on the other hand he states in Narrative Logic, 246, that a Ns or a set of singular statements "may be [my italics] sufficient" to give a historical explanation.

65. For the conception of Lakoff and Johnson see C. Forceville, Pictorial Metaphor in Advertising (Wageningen, 1994), 27-32; for Hesse's conception, see M. Hesse, "Models, Metaphors and Truth," in Knowledge and Language, ed. Ankersmit and Mooij, 50-67. 
damentally metaphorical, and therefore a clear separation between literal and figurative use of language doesn't hold water. Mary Hesse has defended this view which is a defense of realism at the same time: "Just as observation language is theoretical and analogical through and through, but is still the basis for realist descriptions and cognitive inference, so I shall now argue that natural language is metaphorical through and through, and yet has cognitive meaning." "I am going to argue that metaphoric meanings have logical priority over literal meanings in a way analogous to the priority of theoretical over 'observational' meanings in science." ${ }^{66}$ This view is based on the argument that all types of metaphors are built into our ordinary descriptive language. A descriptive statement like "White's theory has no solid foundation in historiography" hides the built-in metaphor "Theories are like buildings." The circumstance that many metaphors are not (any longer) recognized as such does not alter this fact. The enormous advantage of this type of analysis of metaphor is that it does not contradict the truth-claim of historical narratives on a priori grounds and does not implicate any a priori view on the explanatory power of narrative as such. ${ }^{67}$

In my view the truth-claims of history vis-à-vis literature remain essential and therefore cannot be treated as accidental. This crucial difference should prevent philosophers from treating history and fiction as two exemplars of the same species, that of the narrative, of which the historical story, ideally, just happens to be somehow connected to the search for truth. For whenever this happens philosophers of history end up on the wrong track. The stylistic or other textual aspects of history writing then are substituted for history itself, and the philosophical result of this substitution, is that philosophy of history is treated as a branch of aesthetics or of literary theory. This is essentially what has happened during the last two decades and therefore it is no coincidence that many (perhaps even most) books on philosophy of history nowadays are produced in literature departments. $^{68}$

So paradoxically, in the last analysis the fundamental problem with metaphorical philosophy of history turns out to be, all its attention for the linguistic dimensions of history notwithstanding, that it has forgotten to elucidate the linguistic roots of the word "history" itself. For the original meaning of the Greek word historia is not story, but inquiry. And therefore, whenever historical narratives are characterized as "true stories," the emphasis should be put on the adjective and not on the noun.

\section{University of Leiden / Free University of Amsterdam}

66. Hesse, "Models, Metaphors and Truth," 54.

67. In "Literary Theory and Historical Writing" White is moving in this direction by relativizing the differences between the literal and the figurative uses of language without spelling out the consequences for his original position.

68. Cf. Megill and McCloskey, "The Rhetoric of History," 235: "The need is not to abandon epistemological standards. These too are part of the discipline and of its conversation. They mark out a successful attempt to make history, like science, cumulative. Yet at the same time they create an obstacle. History that tries to do without rhetoric loses its contact with the wider conversation of mankind." See also J. Nelson, A. Megill, and D. McCloskey, "Rhetoric of Inquiry," in The Rhetoric of the Human Sciences, ed. Megill and McCloskey, 3-18. 